\title{
Solid-State Dehydration Mechanism of Diclofenac Sodium Salt Hydrates
}

\author{
Hironaga Oyama $^{1}$, Takashi Miyamoto ${ }^{1}$, Akiko Sekine ${ }^{1}$, Ilma Nugrahani ${ }^{2}$ (D) and Hidehiro Uekusa ${ }^{1, *(\mathbb{D})}$ \\ 1 Department of Chemistry, School of Science, Tokyo Institute of Technology, 2-12-1 Ookayama, Meguro-ku, \\ Tokyo 152-8550, Japan; oyama.h.ab@m.titech.ac.jp (H.O.); tmiyamoto388@gmail.com (T.M.); \\ asekine@chem.titech.ac.jp (A.S.) \\ 2 Department of Pharmacochemistry, School of Pharmacy, Bandung Institute of Technology, \\ Bandung 40132, Indonesia; ilma_nugrahani@fa.itb.ac.id \\ * Correspondence: uekusa@chem.titech.ac.jp
}

Citation: Oyama, H.; Miyamoto, T.; Sekine, A.; Nugrahani, I.; Uekusa, H. Solid-State Dehydration Mechanism of Diclofenac Sodium Salt Hydrates. Crystals 2021, 11, 412. https:// doi.org/10.3390/cryst11040412

Academic Editor:

Sławomir Grabowski

Received: 25 February 2021

Accepted: 7 April 2021

Published: 12 April 202

Publisher's Note: MDPI stays neutral with regard to jurisdictional claims in published maps and institutional affiliations.

Copyright: (c) 2021 by the authors. Licensee MDPI, Basel, Switzerland. This article is an open access article distributed under the terms and conditions of the Creative Commons Attribution (CC BY) license (https:// creativecommons.org/licenses/by/ $4.0 /)$.
Abstract: Salt formation is a useful technique for improving the solubility of active pharmaceutical ingredients (APIs). For instance, a nonsteroidal anti-inflammatory drug, diclofenac (DIC), is used in a sodium salt form, and it has been reported to form several hydrate forms. However, the crystal structure of the anhydrous form of diclofenac sodium (DIC-Na) and the structural relationship among the anhydrate and hydrated forms have not yet been revealed. In this study, DIC-Na anhydrate was analyzed using single-crystal X-ray diffraction (XRD). To determine the solid-state dehydration/hydration mechanism of DIC-Na hydrates based on both the present and previously reported crystal structures (4.75-hydrate and 3.5-hydrate), additional experiments including simultaneous powder XRD and differential scanning calorimetry, thermogravimetry, dynamic vapor sorption measurements, and a comparison of the crystal structures were performed. The dehydration of the 4.75-hydrate form was found to occur in two steps. During the first step, only water molecules that were not coordinated to $\mathrm{Na}^{+}$ions were lost, which led to the formation of the 3.5-hydrate while retaining alternating layered structures. The subsequent dehydration step into the anhydrous phase accompanied a substantial structural reconstruction. This study elucidated the complete landscape of the dehydration/hydration transformation of DIC-Na for the first time through a crystal structure investigation. These findings contribute to understanding the mechanism underlying these dehydration/hydration phenomena and the physicochemical properties of pharmaceutical crystals.

Keywords: crystal structure analysis; diclofenac; diclofenac sodium; hydration-dehydration mechanism; hydrate; anhydrate

\section{Introduction}

In drug development, improving the poor water solubility of many active pharmaceutical ingredients (APIs) is an attractive area of research. In addition to the formulation of low-crystallinity solids such as solid dispersions [1,2] and cyclodextrin inclusion compounds [3], other methods can increase solubility through the formation of a stable multi-component crystalline state such as salt formation [4], co-crystallization [5], and salt co-crystallization [6-8], in which the crystal structure differs from the mother API crystal, providing an opportunity to change the solubility. Among these strategies, salt formation is a common method for enhancing the solubility of some APIs with acidic or basic functional groups (carboxy, conjugated hydroxy, amino, etc.) [9,10]. In particular, sodium salt formation is a well-known technique for increasing the solubility of poorly soluble acidic APIs in drug development, and sodium ions account for approximately $60 \%$ of the counter cations of acidic API salts [11].

Sodium API salts often form hydrate crystals in which the water coordination geometry around $\mathrm{Na}^{+}$is more flexible than the structure of the transition metal ion hydrate owing to the s-block atomic nature of $\mathrm{Na}$ [12]. This "pseudo-coordination bond" property 
of $\mathrm{Na}^{+}-\mathrm{O}$ (water) interactions contributes the specific hydration-dehydration behaviors of sodium API salts [13-19].

Hydrate crystals often undergo dehydration according to variations in the ambient temperature or humidity and transform into an anhydrous phase with different physicochemical properties $[20,21]$. Approximately one in three pharmaceutical compounds form hydrate crystals [22], and analyzing the X-ray crystal structure is essential [23] because the physicochemical properties of crystalline materials, such as their solubility [24], hygroscopicity [25,26], and tableting properties [27] depend on their crystal structure [28]. Sometimes, alternations in the crystal structure induced by a dehydration/hydration result in a color change $[29,30]$. For pharmaceutical hydrates, such property changes may affect their bioavailability and safety as pharmaceutical products. Therefore, the structural investigation of polymorphic transitions and the establishment of dehydration mechanisms of drug hydrates are both important processes in drug development [31].

The nonsteroidal anti-inflammatory drug diclofenac (DIC, 2-[2-((2,6-dichlorophenyl) amino)phenyl]acetic acid; Figure 1) is a widely used analgesic, and owing to its high permeability but low solubility, it is categorized as a Biopharmaceutics Classification System (BCS) Class II [32]. Since DIC has an acidic carboxyl group, it can be formulated as a salt with sodium or potassium to improve its solubility. Diclofenac sodium (DIC$\mathrm{Na}$ ) has been reported to form several hydrate crystals (Table S1, the Supplementary Materials). Until now, however, the crystal structure of the anhydrous form of DIC-Na and the structural relationship among this anhydrate and DIC-Na hydrates have not yet been elucidated. The crystal structures of DIC-Na pentahydrate, 4.75 -hydrate $(4.75 \mathrm{H})$, and tetrahydrate were investigated independently, and the reported lattice parameters were almost identical [33-35], implying either that they are isostructural hydrates or that hydrate water molecules are misplaced. The trihydrate has also been recognized in the literature, but its crystal structure is still unknown, and the number of water molecules it contains is not clear [36]. In addition, a hemi-heptahydrate $(3.5 \mathrm{H})$ form was reported very recently [37]. Multi-component crystals of DIC-Na with organic agents such as phenanthroline [38] and L-proline [39] have also been reported. In particular, the DIC solubility achieved by forming the DIC-Na L-proline salt cocrystal was significantly higher than that of DIC-Na [39]. In the DIC-Na L-proline study, a new hydrate form was observed, but the structure was not revealed. Furthermore, in order to complete the overall picture of the DIC-Na hydrate structures, analyzing the crystal structure of the anhydrous form of DIC-Na is essential, which would also establish the complicated hydration-dehydration mechanism of DIC-Na hydrates. The elucidation of such mechanisms is important in the pharmaceutical sciences.

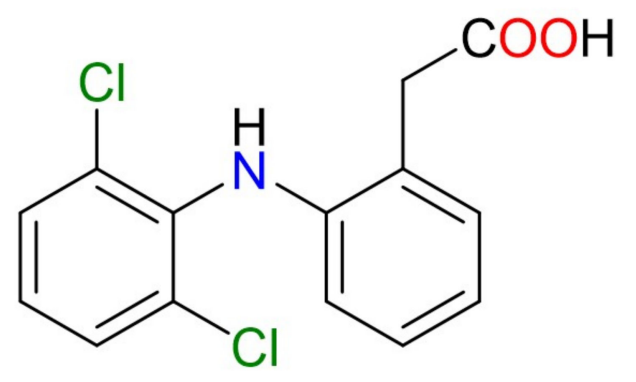

Figure 1. Molecular structure of diclofenac (DIC).

In this study, a novel crystalline phase, anhydrate (AH), was revealed by singlecrystal X-ray diffraction (SCXRD) analysis, and the $4.75 \mathrm{H}$ and $3.5 \mathrm{H}$ crystal structures were re-analyzed for an accurate structural comparison under the same measurement conditions, such as temperature. Simultaneous powder X-ray diffraction (PXRD) and differential scanning calorimetry (DSC) measurements were used to visualize the multistep dehydration process of DIC-Na $4.75 \mathrm{H}$. Based on the crystal structures, the dehydration mechanism of DIC-Na $4.75 \mathrm{H}$ is discussed. 


\section{Materials and Methods}

\subsection{Materials}

DIC-Na (anhydrous) was purchased from Tokyo Chemical Industry Co., Ltd. (Tokyo, Japan). Solvents (tetrahydrofuran, acetonitrile, and methanol) were obtained from Tokyo Chemical Industry Co., Ltd., Nacalai Tesque, Inc. (Kyoto, Japan), and Sigma-Aldrich Japan (Tokyo, Japan), respectively.

\subsection{Preparation of Solid Samples}

\subsubsection{Diclofenac Sodium 4.75-Hydrate}

Dissolving anhydrous DIC-Na (ca. $40 \mathrm{mg}$ ) in distilled water (5 mL) and then slowly evaporating the solution yielded plate-like DIC-Na 4.75-hydrate crystals.

\subsubsection{Diclofenac Sodium Hemiheptahydrate}

Anhydrous DIC-Na (ca. $50 \mathrm{mg}$ ) was dissolved in tetrahydrofuran ( $5 \mathrm{~mL}$ ), followed by the slow evaporation of the solution, which yielded plate-like $3.5 \mathrm{H}$ crystals.

\subsubsection{Diclofenac Sodium Anhydrate}

After dissolving anhydrous DIC-Na (ca. $50 \mathrm{mg}$ ) in a mixed acetonitrile-methanol (4:1 by volume, $5 \mathrm{~mL}$ ) solvent, the solution was subsequently evaporated, resulting in needle-like anhydrous crystals.

\subsection{Powder X-ray Diffraction (PXRD)}

PXRD was performed using SmartLab (Rigaku, Japan) in the manner of transmission geometry. The data were collected from $2 \theta=3^{\circ}$ to $40^{\circ}$ at an ambient temperature at step and scan speeds of $0.01^{\circ}$ and $3^{\circ} \mathrm{min}^{-1}$, respectively, using a $\mathrm{Cu} \mathrm{K} \alpha$ source $(45 \mathrm{kV}, 200 \mathrm{~mA})$. The conditions for simultaneous PXRD and DSC measurements are discussed in Section 2.6.

\subsection{Single-Crystal X-ray Diffraction (SCXRD)}

Single crystals of DIC-Na hydrates and anhydrate were prepared by the method described in Section 2.2, and the SCXRD data were collected using R-AXIS RAPID (Rigaku Tokyo, Japan) with Mo K $\alpha$ radiation $(\lambda=0.71075 \AA$ ). Data reduction and correction were performed using RAPID-AUTO (Rigaku) with ABSCOR (T. Higashi Rigaku, Tokyo, Japan). The space group was determined using PLATON [40]. The structure was solved using a dual-space algorithm of SHELXT [41] and then refined on $F^{2}$ using SHELXL-2017/1 [42]. All non-hydrogen atoms were refined anisotropically. Hydrogen atoms attached to oxygen (water) and nitrogen atoms were found in the differential Fourier map. The water hydrogen atoms were refined using standard distance restraints and constrained isotropic thermal parameters. The hydrogen atoms attached to nitrogen were refined with lax distance restraints of $0.88 \AA$ and thermal parameters set to 1.2 times those of the parent atom. Other hydrogen atoms were located in the geometrically calculated position and refined using the riding model. The 3D structures of the molecules were drawn using Mercury 4.3.1 [43].

\subsection{Thermogravimetric (TG) Analysis}

Thermogravimetric (TG) and differential thermal analysis (DTA) measurements were performed using a Thermo plus EVO (Rigaku, Tokyo, Japan). A sample of powdery $4.75 \mathrm{H}$ $(7.856 \mathrm{mg})$ in an unsealed aluminum pan was heated at $5^{\circ} \mathrm{C} \mathrm{min}^{-1}$ up to $150{ }^{\circ} \mathrm{C}$ under flowing $\mathrm{N}_{2}$ gas $\left(100 \mathrm{~mL} \mathrm{~min}^{-1}\right)$.

\subsection{Differential Scanning Calorimetry (DSC)}

PXRD and DSC measurements were performed simultaneously using an XRD-DSC (Rigaku, Japan) equipped with a D/tex Ultra detector and $\mathrm{Cu} \mathrm{K} \alpha$ source $(40 \mathrm{kV}, 40 \mathrm{~mA})$. A powdery sample of DIC-Na $4.75 \mathrm{H}$ was heated at $+1{ }^{\circ} \mathrm{C} \mathrm{min}^{-1}$ up to $120^{\circ} \mathrm{C}$ in an unsealed Al pan with flowing $\mathrm{N}_{2}$ gas $\left(100 \mathrm{~mL} \mathrm{~min}^{-1}\right)$. The preliminary DSC measurement was 
performed up to $300{ }^{\circ} \mathrm{C}$ to confirm the absence of phase transformation over $150{ }^{\circ} \mathrm{C}$ (Figure S1, the Supplementary Materials).

\subsection{Dynamic Vapor Sorption (DVS)}

The critical relative humidity $(\mathrm{RH})$ where the hydration of the anhydrous DIC-Na AH occurs was determined by dynamic vapor sorption (DVS) using a Dynamic Vapor Sorption Advantage instrument (Surface Measurement Systems Ltd., Wembley, UK) at $25^{\circ} \mathrm{C}$. The $\mathrm{RH}$ was increased from $0 \%$ to $90 \%$ and then decreased to $0 \%$ with a step width of $5 \%$.

\section{Results}

\subsection{Crystal Structure of DIC-Na Hydrates}

The crystal structures of DIC-Na $4.75 \mathrm{H}, 3.5 \mathrm{H}$, and AH were successfully analyzed by SCXRD, and the crystallographic data are shown in Table 1 . The phase agreement between the solid powder samples obtained by the method described in Section 2.2 and the analyzed single crystals was confirmed by their PXRD patterns.

Table 1. Crystallographic data of diclofenac sodium (DIC-Na) hydrates and anhydrate.

\begin{tabular}{cccc}
\hline & $4.75 \mathrm{H}$ & $3.5 \mathrm{H}$ & AH \\
\hline Chemical formula & $\mathrm{C}_{14} \mathrm{H}_{10} \mathrm{Cl}_{2} \mathrm{NNaO}_{2}$ & $\mathrm{C}_{14} \mathrm{H}_{10} \mathrm{Cl}_{2} \mathrm{NNaO}_{2}$ & $\mathrm{C}_{14} \mathrm{H}_{10} \mathrm{Cl}_{2} \mathrm{NNaO}_{2}$ \\
Formula weight & $4.75\left(\mathrm{H}_{2} \mathrm{O}\right)$ & $3.5\left(\mathrm{H}_{2} \mathrm{O}\right)$ & 318.12 \\
Temperature/K & 403.69 & 381.17 & 173 \\
Crystal system & 173 & 173 & Orthorhombic \\
Space group & Monoclinic & Triclinic & $P b c a$ \\
$a / \AA$ & $P 2_{1}$ & $P \overline{1}$ & $26.3664(5)$ \\
$b / \AA$ & $9.5552(3)$ & $9.3628(3)$ & $6.44256(12)$ \\
$c / \AA$ & $39.5393(8)$ & $9.4844(3)$ & $32.8255(6)$ \\
$\alpha /^{\circ}$ & $9.8346(2)$ & $19.0742(6)$ & 90 \\
$\beta /{ }^{\circ}$ & 90 & $90.1187(11)$ & 90 \\
$\gamma /{ }^{\circ}$ & $90.7122(8)$ & $99.5439(12)$ & 90 \\
Volume $/ \AA^{3}$ & 90 & $90.5134(11)$ & $5575.97(18)$ \\
$Z, Z^{\prime}$ & $3715.28(16)$ & $1670.28(9)$ & 16,2 \\
Density/g cm & 8,3 & 4,2 & 1.516 \\
$R\left[F^{2}>2 \sigma\left(F^{2}\right)\right]$ & 1.443 & 1.516 & 0.0646 \\
$C C D C$ number & 0.0379 & 0.0347 & 2065086 \\
\hline
\end{tabular}

The lattice parameters of DIC-Na 4.75H shown in Table 2 are identical to those reported by Llinàs et al. (Table S1) [34]. The asymmetric unit contained four DIC anions and 19 water molecules (Figure 2). $\mathrm{Na}^{+}$ions were surrounded by a large amount of water, and $\mathrm{Na}^{+}$ was coordinated to either six or five water molecules (6-coordination or 5-coordination, respectively), while DIC anions formed no coordination bonds with $\mathrm{Na}^{+}$ions. Five of the 19 water molecules did not coordinate with $\mathrm{Na}^{+}$ions and existed as crystalline water molecules in the crystal.

Similarly, the lattice parameters of DIC-Na $3.5 \mathrm{H}$ in Table 1 are the same as those reported by Nieto et al. (Table S1) [37]. DIC-Na 3.5H crystallized in the triclinic P $\overline{1}$ space group, and its asymmetric unit, consisted of two DIC anions, two $\mathrm{Na}^{+}$cations, and seven water molecules (Figure 3). All water in the crystal was bound to $\mathrm{Na}^{+}$. One $\mathrm{Na}^{+}$ion was coordinated to either five water oxygens and a carboxylate oxygen or to four water oxygens and two carboxylate oxygens of DIC, resulting in a 6-coordination configuration in both cases (Figure 4). Although the unit cell of $3.5 \mathrm{H}$ was relatively similar to that of $4.75 \mathrm{H}$, its crystallographic symmetry was reduced from monoclinic to triclinic. 


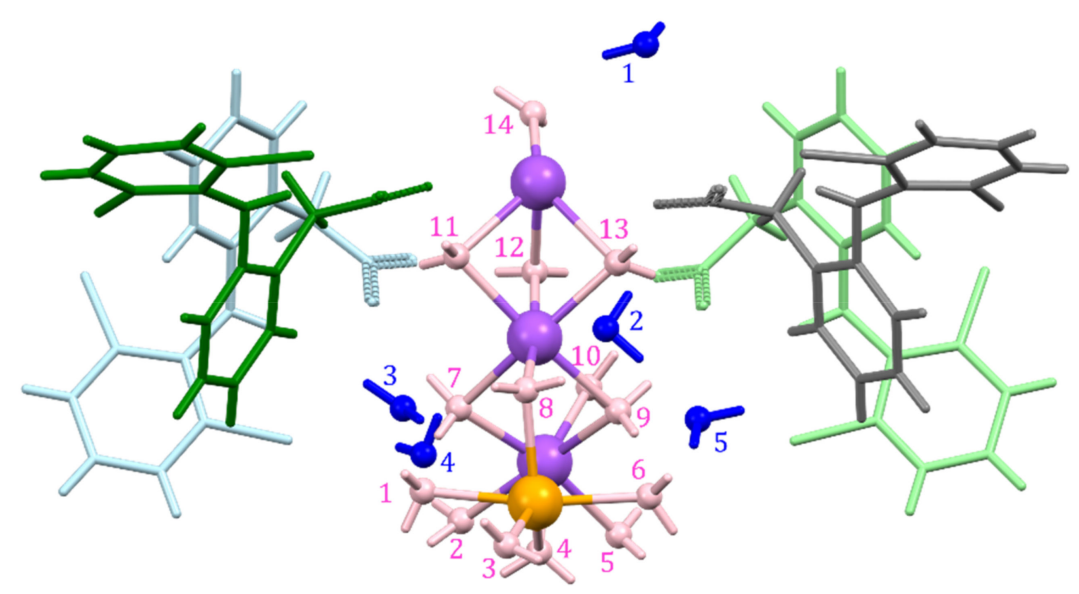

Figure 2. Asymmetric unit of DIC-Na $4.75 \mathrm{H}$, with fourteen bonded (pink) and five non-bonded (blue) water molecules and 6-coordinated (purple) and 5-coordinated (orange) $\mathrm{Na}^{+}$ions.

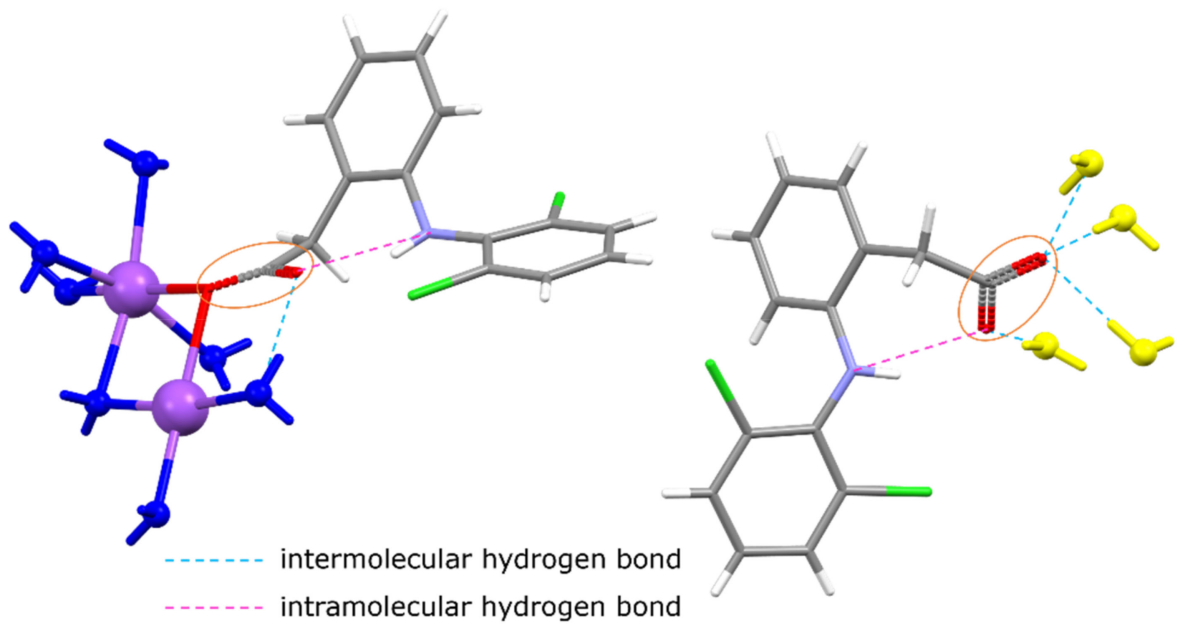

Figure 3. Asymmetric unit of DIC-Na 3.5H (yellow water molecules are not included). One (left) DIC is connected to $\mathrm{Na}^{+}$ions, but the other (right) forms hydrogen bonds with water and does not bond with $\mathrm{Na}^{+}$ions.

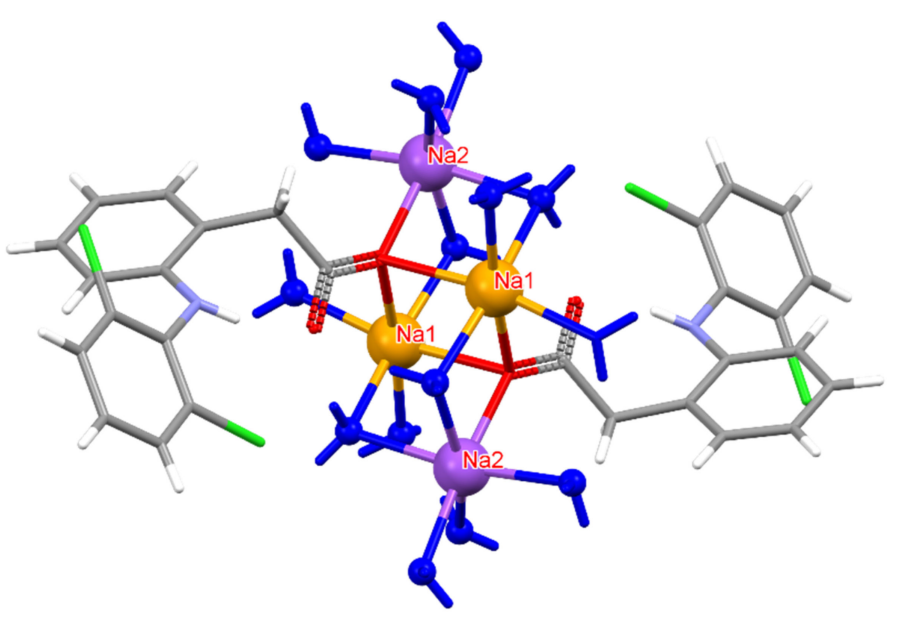

Figure 4. Coordination environment around $\mathrm{Na}^{+}$ions in DIC-Na 3.5H. Na2 (purple) is connected to five $\mathrm{H}_{2} \mathrm{O}$ oxygens and one carboxylate oxygen, whereas $\mathrm{Na}$ 1 (orange) bonds to four $\mathrm{H}_{2} \mathrm{O}$ oxygens and two carboxylate oxygens. However, in both cases, Na adopts a six-coordinated configuration. 
For the first time, this work elucidated the crystal structure of DIC-Na AH, which crystallizes into an orthorhombic system with the Pbca space group, wherein two DIC anions and sodium cations are independent (Figure 5). In contrast to $4.75 \mathrm{H}$ and $3.5 \mathrm{H}$, $\mathrm{AH}$ does not show an alternating layered structure consisting of a hydrophilic region $\left(\mathrm{Na}^{+}\right.$, water, and carboxylate) and hydrophobic region (the main part of DIC) (Figure 6). However, a one-dimensional hydrophilic $\mathrm{Na}-\mathrm{O}$ chain structure appears along the $b$-axis in the $\mathrm{AH}$ crystal, where $[\mathrm{Na}-\mathrm{O}]_{2}$ squares and $[\mathrm{Na}-\mathrm{OCO}$ (carboxylate)] kites are connected alternately to form an infinite rigid chain (Figure 7). In the crystal structure, each $\mathrm{Na}^{+}$ion is coordinated to five carboxylate oxygens (three monodentate carboxylates and one bidentate carboxylate) and adopts a 5-coordinated geometry. To visualize the conformational differences in the two independent DIC anions in the asymmetric unit, they are overlaid in Figure 8, which demonstrates great variation at the carboxylate moiety and the second aromatic ring with chlorine atoms.

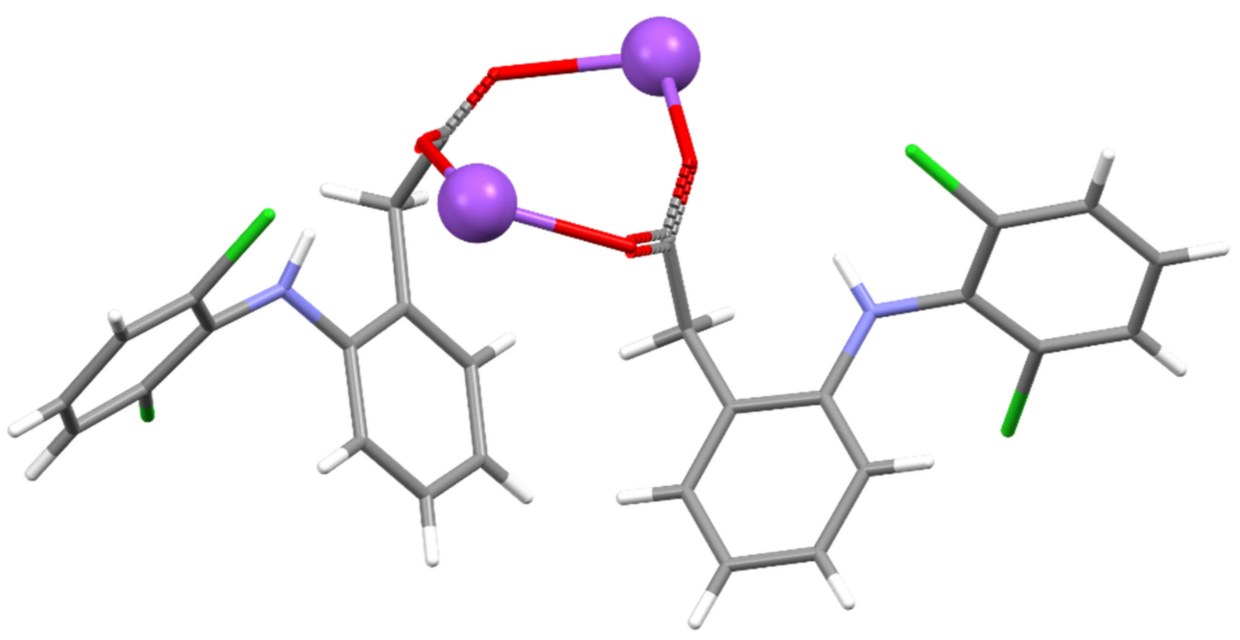

Figure 5. Asymmetric unit of DIC-Na AH.

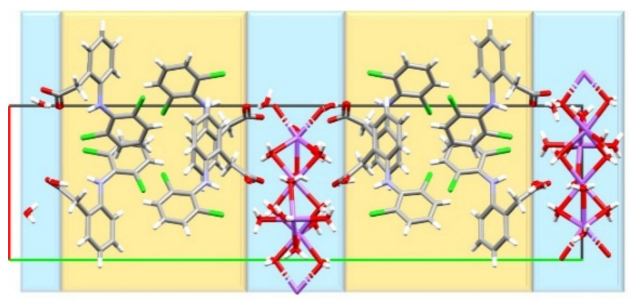

$4.75 \mathrm{H}$

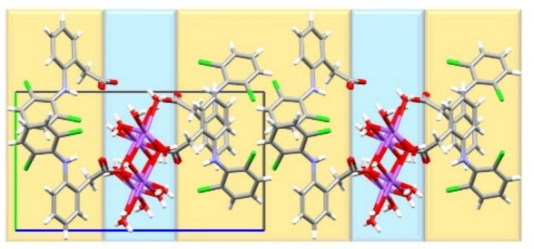

$3.5 \mathrm{H}$

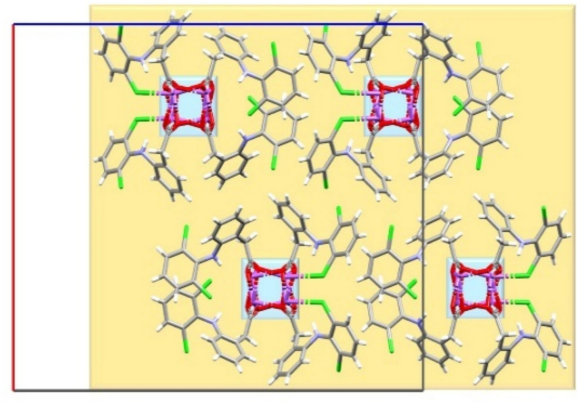

$\mathrm{AH}$

Figure 6. Structural comparison among unit cells of three DIC-Na hydrates. 

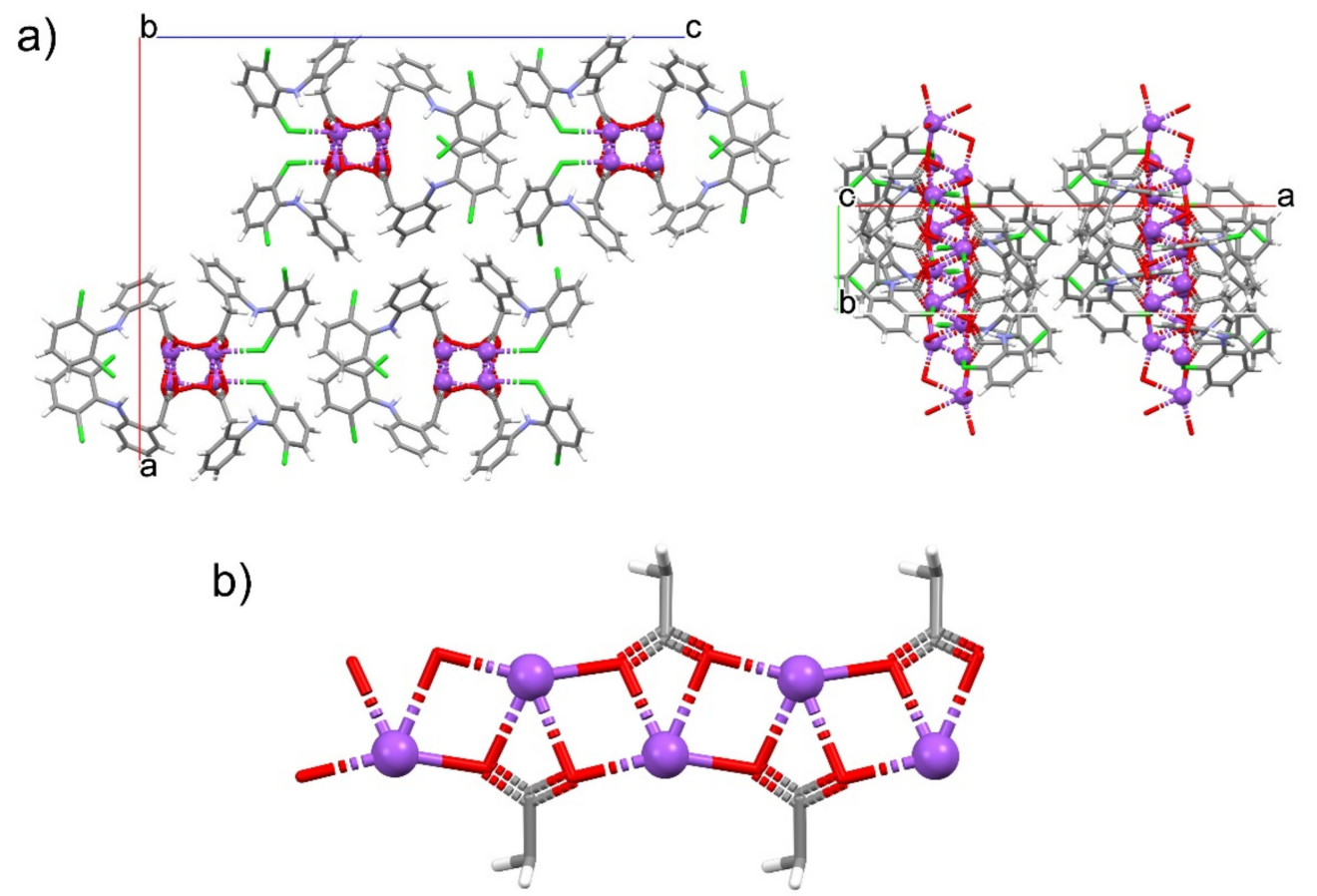

Figure 7. One-dimensional Na-O chain in DIC-Na AH. (a) Crystal packing diagrams viewed from the b- (left) and c-axes (right). (b) Infinite motif composed of $\mathrm{Na}-\mathrm{O}-\mathrm{Na}-\mathrm{O}$ squares and $\mathrm{Na}-\mathrm{O}-\mathrm{C}-\mathrm{O}$ kites.

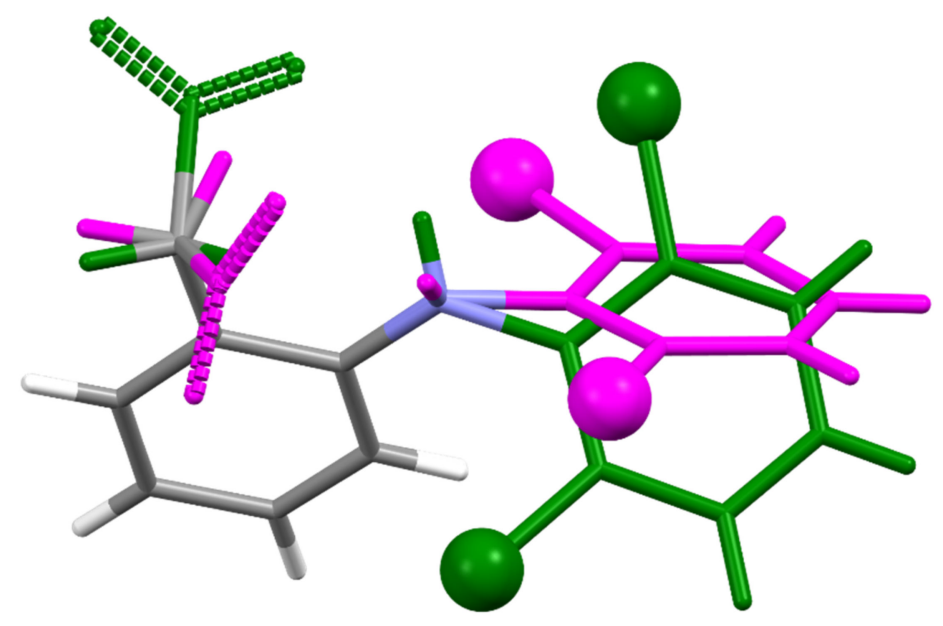

Figure 8. Structural overlay between two independent DIC molecules in DIC-Na AH shown in Figure 5.

The consistency between the powdery materials used in subsequent experiments and the single-crystalline phases was confirmed using their PXRD patterns, and the patterns of the experimental samples were verified to be identical to those calculated from the crystal structure via Mercury 4.3.1 (Figure 9) [43].

\subsection{Dehydration Behavior of DIC-Na $4.75 \mathrm{H}$}

The dehydration of DIC-Na $4.75 \mathrm{H}$ was examined by simultaneous PXRD-DSC measurements, and the results are presented in Figure 10. The preliminary DSC measurement was performed up to $300{ }^{\circ} \mathrm{C}$ to show there was no change from the dehydration temperature $\left(108.4{ }^{\circ} \mathrm{C}\right)$ to the melting point of DIC-Na $\left(292.4^{\circ} \mathrm{C}\right)$ (Figure S1). Therefore, the PXRD-DSC and the TG-DTA data (Figure 11) were collected up to $120^{\circ} \mathrm{C}$ and $150{ }^{\circ} \mathrm{C}$, respectively. The DSC curve showed two endothermic peaks corresponding to multi-step dehydration transitions. After the first transition, the PXRD pattern changed slightly, indi- 
cating the emergence of a hemi-heptahydrate phase (i.e., 3.5H). The second transition led to a distinct pattern derived from an anhydrous phase. Because the second peak bifurcated, the second dehydration may be a multi-step process, and $3.5 \mathrm{H}$ may transform into $\mathrm{AH}$ via intermediate phases.

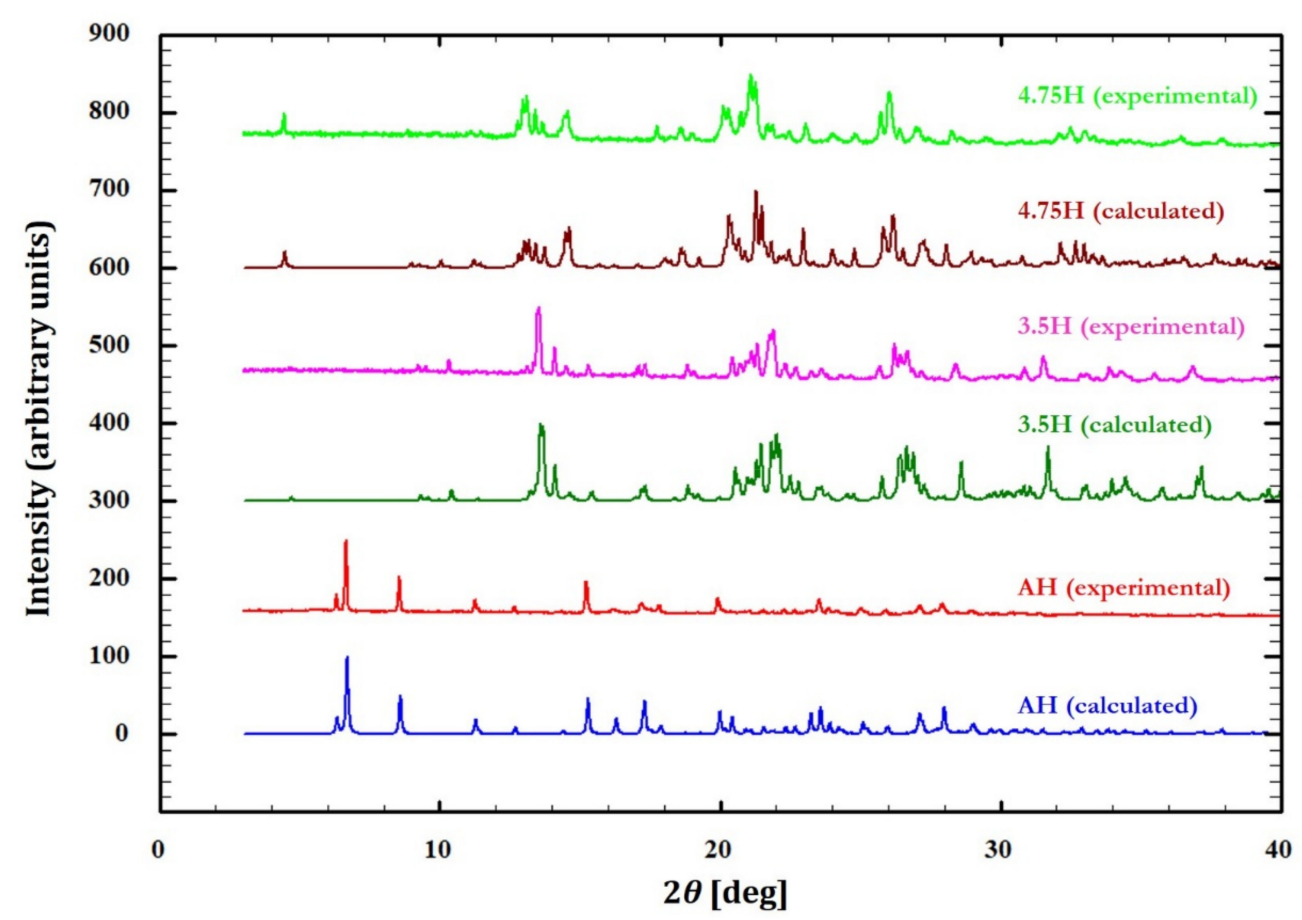

Figure 9. Experimental and calculated powder X-ray diffraction (PXRD) patterns for DIC-Na 4.75H, $3.5 \mathrm{H}$, and $\mathrm{AH}$ forms.
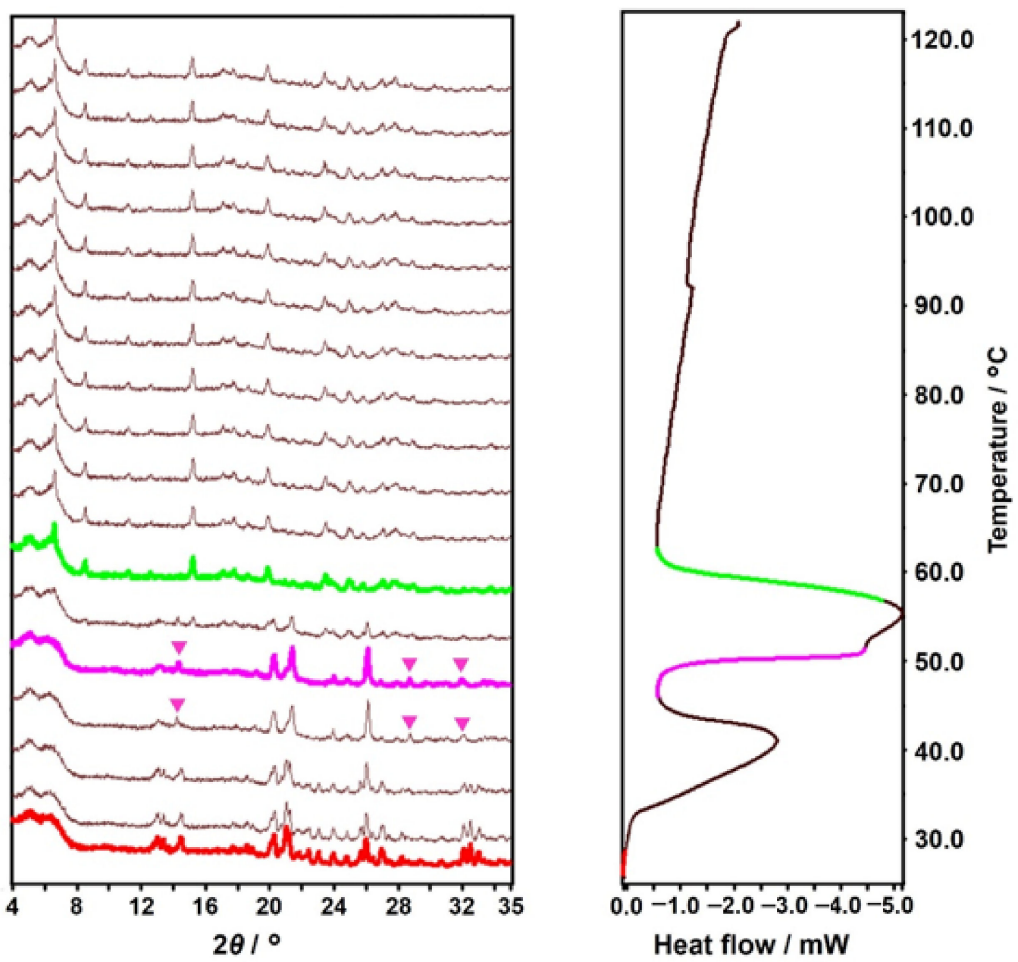

Figure 10. Simultaneously measured variable-temperature powder X-ray diffraction (PXRD) (left) and differential scanning calorimetry (DSC) (right) diagrams. The colored PXRD patterns and segments in the DSC diagram correspond to the emergence of new phases. 


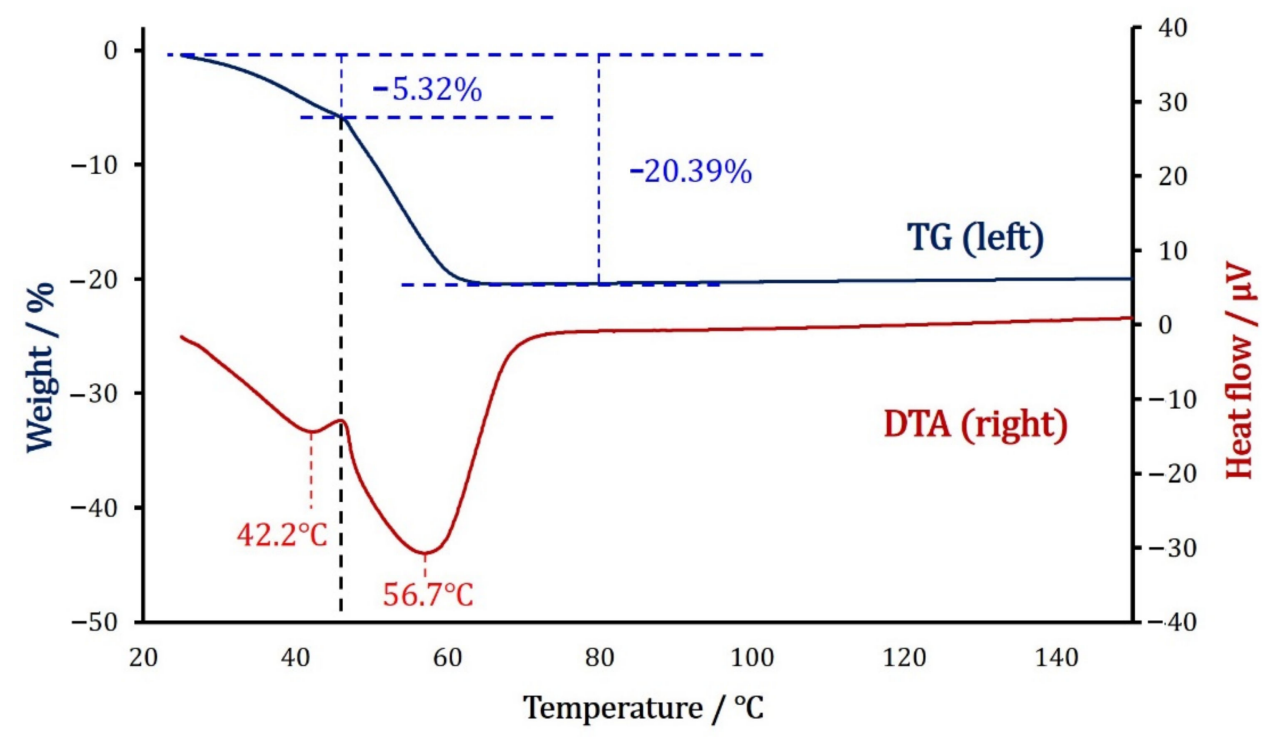

Figure 11. Thermogravimetric (TG) (left axis) and differential thermal analysis (DTA) (right axis) diagrams of DIC-Na $4.75 \mathrm{H}$.

The TG-DTA curves in Figure 11 exhibit the dehydration behavior in further detail. Two DTA endothermic peaks appear. The first peak $\left(42.2^{\circ} \mathrm{C}\right)$ is accompanied by a $5.32 \%$ weight decrease, indicating partial dehydration ( 4.75 to 3.5 , calculation: $5.58 \%$ ), which is followed by the second peak $\left(56.7^{\circ} \mathrm{C}\right)$ with a $15.07 \%$ weight decrease, which corresponds to complete dehydration (3.5 to 0 , calculation: $16.54 \%$ ).

The DVS experiments performed at $25{ }^{\circ} \mathrm{C}$ revealed hysteresis between the water sorption and desorption processes (Figure 12). During the sorption process, AH started to absorb water at $60 \% \mathrm{RH}$ and transformed into $4.75 \mathrm{H}$ at $65 \% \mathrm{RH}$. On the other hand, during the desorption process, $4.75 \mathrm{H}$ was almost stable down to $35 \% \mathrm{RH}$ but started to desorb water at $30 \% \mathrm{RH}$ and completely changed into $\mathrm{AH}$ at $30 \% \mathrm{RH}$. The intermediate $3.5 \mathrm{H}$ form (simulation: $19.8 \%$ mass change) was not observed during the desorption process.

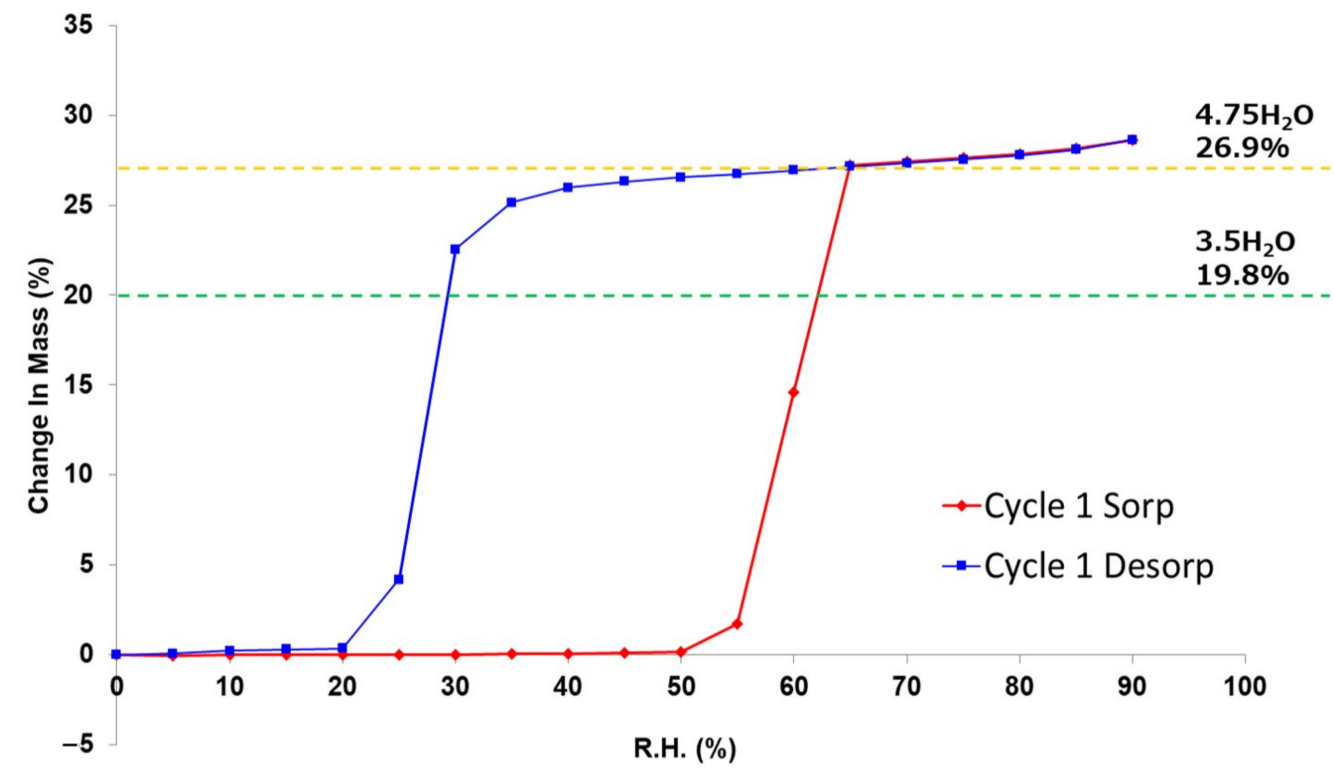

Figure 12. Dynamic vapor sorption (DVS) isotherm plot at $25^{\circ} \mathrm{C}$ of DIC-Na anhydrate (AH). 


\section{Discussion}

\subsection{Verification of the Validity of the 4.75-Hydrate Crystal Structure}

The published crystal structures of pentahydrate, $4.75 \mathrm{H}$, and tetrahydrate have very similar lattice constants but different water contents. Moreover, the space group of $4.75 \mathrm{H}$ is $P 2_{1}$, whereas those of the pentahydrate and tetrahydrate forms are both $P 2_{1} / m[33,35]$. The crystal structure of DIC-Na $4.75 \mathrm{H}$ contains a pseudo-mirror plane between two corresponding DIC anions. However, the shape of the cluster of $\mathrm{Na}^{+}$ions and water molecules is greatly distorted from the mirror symmetry, so it is not suitable to set the mirror plane on this cluster. The published pentahydrate structure was solved in the $P 2_{1} / m$ space group by employing a disordered model at the position of $\mathrm{Na}^{+}$ions [33]. However, this assignment of the occupancy of disordered water may have been incorrect. The present study revealed that, in one unit cell, four DIC-Na molecules are associated with not 20 but 19 water molecules ( 4.75 water molecules for one DIC anion) in the hydrated solid state. Notably, the $4.75 \mathrm{H}$ structure model reported by Llinàs et al. was validated by a low $R$ factor in their structural refinement [34].

Figure 13 shows the Na-O coordination network observed in the crystal structure of DIC-Na 4.75H. Three 6-coordinated sodium ions ( $\mathrm{Na} 1, \mathrm{Na} 2$, and $\mathrm{Na}$ ) form a waving [Na$\mathrm{O}-\mathrm{Na}-\mathrm{O}]$ chain structure, while a 5-coordinated sodium ion ( $\mathrm{Na} 4$, orange) is connected to the chain via water. The lower panel in Figure 13 displays the chain seen from the direction parallel to the pseudo-mirror plane. Although most atoms have a corresponding atom across the pseudo-mirror plane, one water molecule (red) does not. A different Fourier map exhibited a $0.36 \mathrm{e}^{-3}$ residual electron peak at the corresponding position, which might indicate a water oxygen. However, refining such a model was difficult because the occupancy factor decreased to less than $8 \%$, and the position was unstable. Thus, we concluded that the residual error is not significant, and the phase contains 4.75 water molecules.
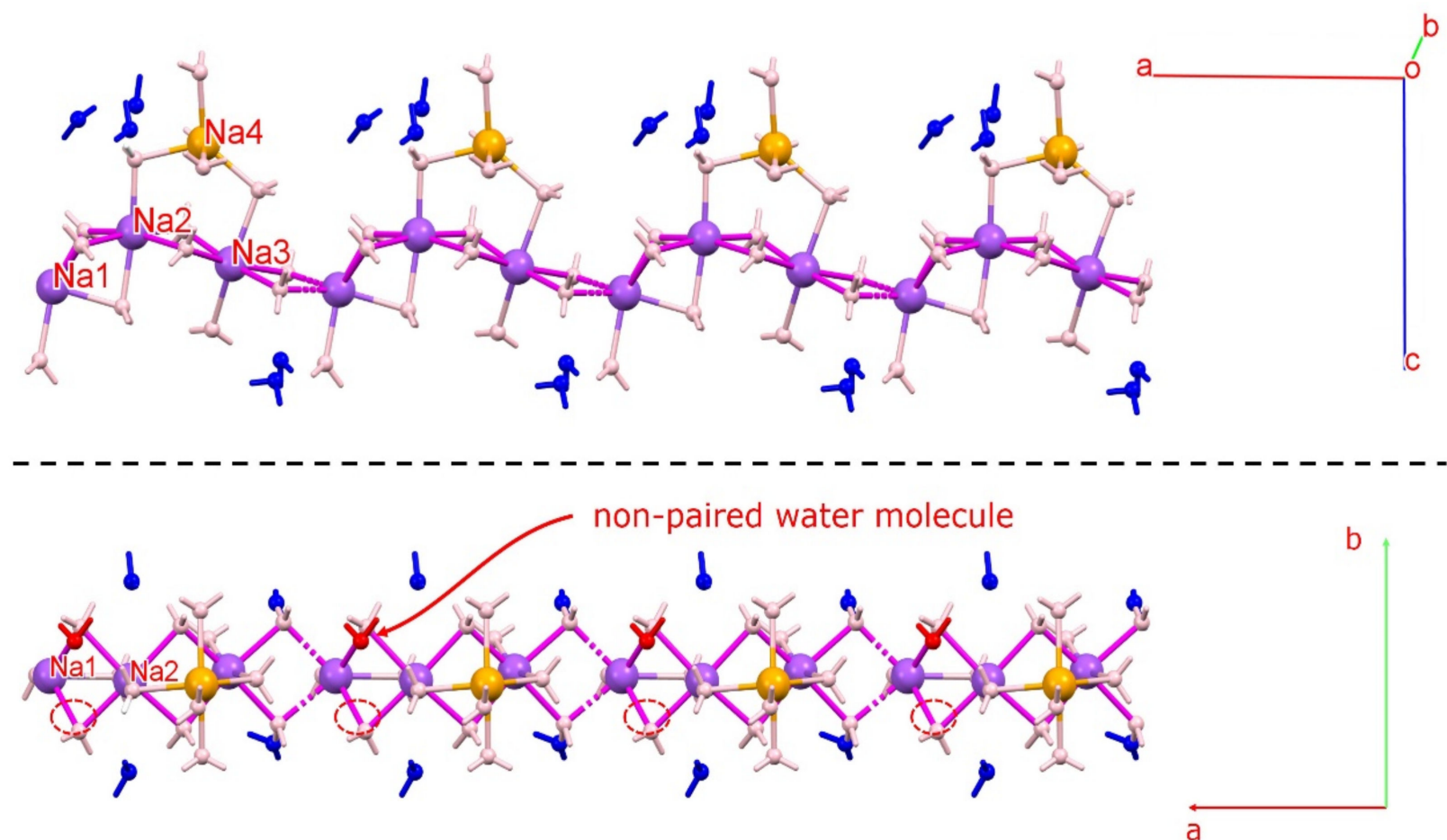

Figure 13. Na-O chain observed in the crystal structure of $4.75 \mathrm{H}$. Three 6-coordinated sodium ions ( $\mathrm{Na} 1, \mathrm{Na} 2, \mathrm{and} \mathrm{Na} 3)$ form a waving [Na-O-Na-O] chain structure. Red water molecules do not have an associated atom across the pseudo-mirror plane (non-paired water molecule). Figures were drawn with crystallographic a, b, c-axis marks. 


\subsection{Hydration and Dehydration Mechanism 4.75H Crystal}

DIC-Na AH sorbs water molecules and directly transforms into $4.75 \mathrm{H}$, which does not include the $3.5 \mathrm{H}$ form. In contrast, DIC-Na $4.75 \mathrm{H}$ loses water and transforms first into $3.5 \mathrm{H}$ and then into $\mathrm{AH}$. The difference between the hydration and dehydration behaviors can be explained based on the similarity of the crystal structures.

According to the DVS isotherm sorption plot (Figure 12, red), the DIC-Na AH form was stable in a humid environment up to $50 \% \mathrm{RH}$. However, it rapidly absorbed water to form DIC-Na $4.75 \mathrm{H}$ at $65 \% \mathrm{RH}$. The DIC-Na $3.5 \mathrm{H}$ form did not appear in the absorption process. This stoichiometric absorption behavior may be due to the large difference in the crystal structures between DIC-Na $\mathrm{AH}$ and $4.75 \mathrm{H}$ (Figure 6). In fact, the alternating layered structure of hydrophilic and hydrophobic regions in $3.5 \mathrm{H}$ and $4.75 \mathrm{H}$ forms was not observed in the AH form. Usually, a large hysteresis in the DVS isotherm plot (Figure 12) indicates a large difference in the crystalline structure. The AH form may be kinetically stable owing to such a difference that it did not rapidly change into hydrate phases. The hydration critical $\mathrm{RH}$ of $65 \% \mathrm{RH}$ in the $\mathrm{AH}$ form exceeded the stable region of the $3.5 \mathrm{H}$ form ( 30 to $60 \% \mathrm{RH}$ ), which prevented the formation of $3.5 \mathrm{H}$ during the hydration of the $\mathrm{AH}$ form.

In the case of dehydration, the DVS isotherm desorption plot (Figure 12, blue) reveals that DIC-Na $4.75 \mathrm{H}$ was stable down to $65 \% \mathrm{RH}$. Then, it gradually released water and transitioned to $3.5 \mathrm{H}$, which was stable between $65 \%$ and $30 \%$ RH. Below $30 \% \mathrm{RH}$, the $3.5 \mathrm{H}$ form rapidly when transformed to the $\mathrm{AH}$ form. The smooth dehydration from $4.75 \mathrm{H}$ to $3.5 \mathrm{H}$ can be explained by their similar crystal structure, with analogous hydrophilic/hydrophobic alternating layers (Figure 6). In the TG-DTA curve (Figure 11), which was recorded under flowing dry $\mathrm{N}_{2}$ gas, a partial stoichiometric weight loss (5.32\%) confirmed the presence of $3.5 \mathrm{H}$ at approximately $50{ }^{\circ} \mathrm{C}$. Similarly, the simultaneous PXRD-DSC measurements (Figure 10) showed the first dehydration step to generate $3.5 \mathrm{H}$, and a few $2 \theta$ diffraction peaks revealing the presence of $3.5 \mathrm{H}$ were observed at $14^{\circ}, 29^{\circ}$, and $32^{\circ}$ (indicated by pink markers in Figure 10). Together, these results suggested a mechanistic aspect of this transition, namely that it was not until the crystal lattice of $4.75 \mathrm{H}$ could no longer accommodate the void structures formed during dehydration in which another lattice emerged, which corresponded to that of $3.5 \mathrm{H}$. In this manner, the reported "tetrahydrate" structure with the same cell dimensions as $4.75 \mathrm{H}$ [35] might arise from the partial decrease in the occupancies of water molecules.

The change in the crystal structure from $4.75 \mathrm{H}$ to $3.5 \mathrm{H}$ is illustrated in Figure 14 . Out of the 19 water molecules in the unit cell of $4.75 \mathrm{H}$, the five that do not interact with $\mathrm{Na}^{+}$ were released during dehydration to form $3.5 \mathrm{H}$ (i.e., the ratio of water/DIC reduced from 19:4 (4.75) to 14:4 (3.5)). Thus, water molecules bonded to their surrounding molecules only through classical $\mathrm{OH} \cdots$ O hydrogen bonds were preferentially lost by dehydration. This mechanism is consistent with the previous conjecture by Bartolomei et al. that some water molecules were tightly bound and immobile, while the others were highly mobile [36].

The release of five water molecules during the dehydration changed the coordination environment around $\mathrm{Na}^{+}$. The number of $\mathrm{Na}^{+} \ldots \mathrm{O}$ interactions is summarized in Table 2 with other crystallographic indices. During dehydration from $4.75 \mathrm{H}$ to $3.5 \mathrm{H}$, the number of $\mathrm{Na}^{+} \ldots \mathrm{O}$ (water) interactions decreased, but new $\mathrm{Na}^{+} \ldots \mathrm{O}$ (carboxylate) interactions formed to compensate for this decrease, thereby maintaining either five or six $\mathrm{Na}^{+} \ldots \mathrm{O}$ (all) interactions per one $\mathrm{Na}^{+}$. This change in the $\mathrm{Na}^{+}$coordination environment implies that the coordination of $\mathrm{Na}^{+}$with $\mathrm{O}$ is flexible, allowing a smooth change in the coordinating atom from $\mathrm{O}$ (water) to $\mathrm{O}$ (carboxylate). In addition, a coordination number of 5 or 6 around $\mathrm{Na}^{+}$in $4.75 \mathrm{H}$ is commonly observed, and more than 6-coordination is undesirable owing to steric hindrance [44]. 


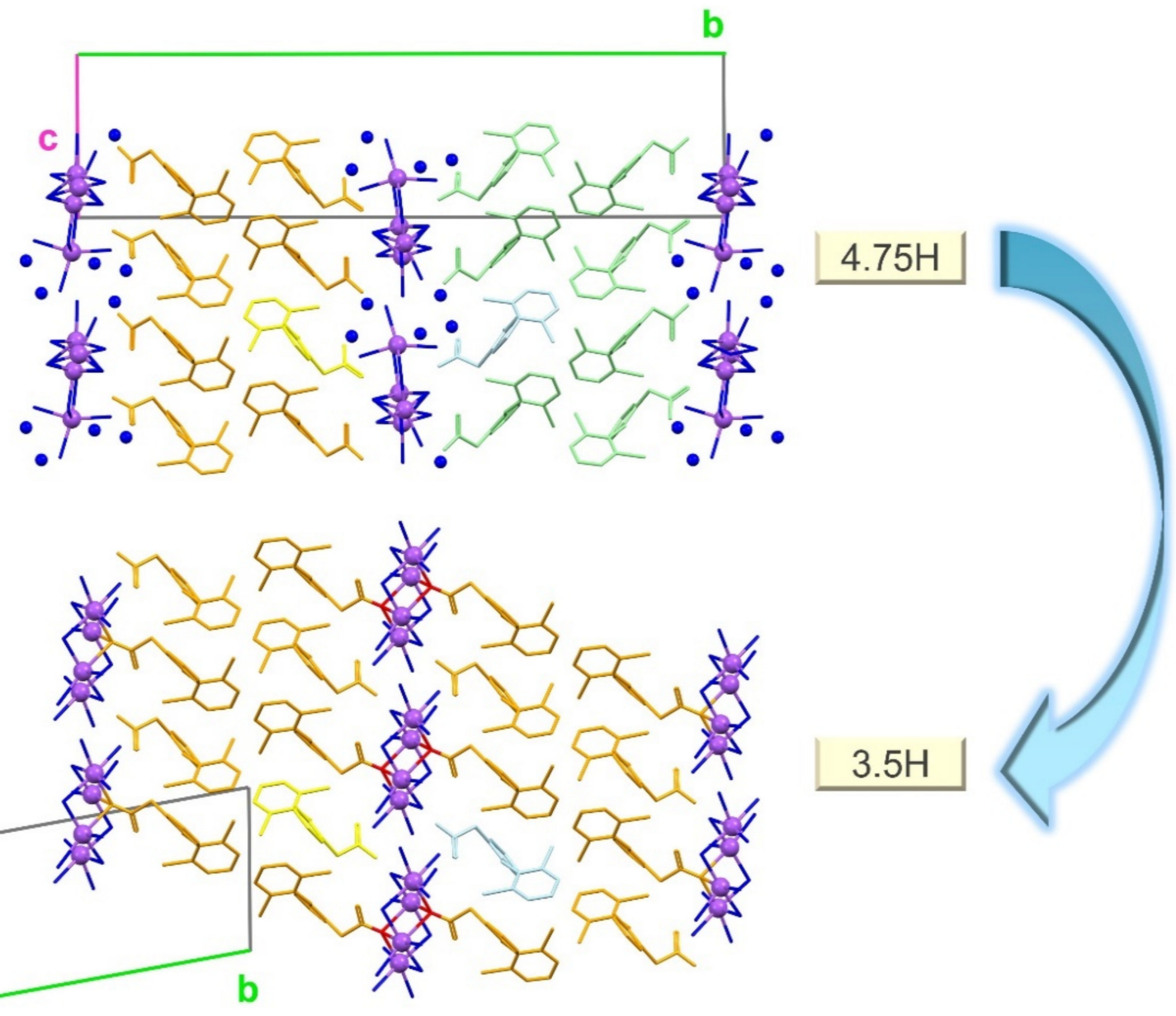

Figure 14. Structural changes during the dehydration from $4.75 \mathrm{H}$ to $3.5 \mathrm{H}$. Non-bonded water molecules are represented by blue spheres. Hydrogen atoms are omitted. Figures were drawn with crystallographic a, b, c-axis marks.

During dehydration, the orientation of the DIC molecules changed. Both the $4.75 \mathrm{H}$ and $3.5 \mathrm{H}$ forms have hydrophobic DIC layer structures, but the directions of these layers differ. Specifically, the alternating layers in the crystal structure of $4.75 \mathrm{H}$ are oriented in the opposite direction (orange and light-green in Figure 14), whereas the layers in $3.5 \mathrm{H}$ are in the same direction (orange only). This change is highlighted by the yellow and light-blue molecules in Figure 14. During dehydration, the yellow molecule retained the same orientation in both structures, but the light blue one rotated. This rotation may have facilitated the breaking and formation of $\mathrm{Na}^{+} \ldots \mathrm{O}$ (water or carboxylate) interactions associated with structural reconstruction.

A large rearrangement in the crystal structure of the $\mathrm{AH}$ form was observed below $30 \% \mathrm{RH}$. During this change, the hydrophilic/hydrophobic alternating-layer structure disappeared, and a one-dimensional chain structure of hydrophilic $\left(\mathrm{Na}^{+}\right.$and $\left.\mathrm{O}\right)$ formed along the b-axis (Figure 7). Although this change was large, $\mathrm{O}$ (carboxylate) atoms almost maintained the $\mathrm{Na}^{+}$coordination number at five. The packing indices (Table 2) were calculated using the PLATON program [40]. The packing index of $4.75 \mathrm{H}$ is slightly lower than that of $3.5 \mathrm{H}$, possibly due to a small void space (ca. $5.9 \AA^{3} \times 2$ ), which would explain why the slightly unstable $4.75 \mathrm{H}$ starts to dehydrate to $3.5 \mathrm{H}$, even in the high $\mathrm{RH}$ region. Meanwhile, compared with $\mathrm{AH}$, the $3.5 \mathrm{H}$ form is more efficiently packed, utilizes a greater number of $\mathrm{H}$-bonds, and has more water molecules filling spaces. 
Table 2. Number of $\mathrm{Na}^{+}-\mathrm{O}$ interactions and packing indices.

\begin{tabular}{cccc}
\hline & $\mathbf{4 . 7 5 H}$ & $\mathbf{3 . 5 H}$ & $\mathbf{A H}$ \\
\hline No. of water molecules per four DIC molecules & 19 & 14 & 0 \\
$\mathrm{Na}^{+}-\mathrm{O}$ (all) interactions & 6 or 5 & 6 & 5 \\
$\mathrm{Na}^{+}-\mathrm{O}$ (water) interactions & 6 or 5 & 5 or 4 & 0 \\
$\mathrm{Na}^{+}-\mathrm{O}$ (carboxylate) interactions & 0 & 1 or 2 & 5 \\
Packing index & 70.3 & 73.3 & 71.9 \\
\hline
\end{tabular}

\section{Conclusions}

The novel crystalline phase of DIC-Na AH was revealed by SCXRD. The re-determination of the crystal structure and crystallographic investigation of $4.75 \mathrm{H}$ showed that the presence of non-coordinated water molecules caused pseudo-symmetry and structural complexity. The multi-step dehydration mechanism of DIC-Na $4.75 \mathrm{H}$ was successfully elucidated using simultaneous PXRD-DSC, TG, and DVS, as well as a comparison of the crystal structures. During the first dehydration step, only water molecules that were not coordinated to $\mathrm{Na}^{+}$ ions were lost, which led to the generation of $3.5 \mathrm{H}$. The second dehydration step into the anhydrous phase $(\mathrm{AH})$ was accompanied by a large structural change. For the first time, this work successfully elucidated the solid-state dehydration transition landscape of DIC-Na, which is a commercially available form of this API, using X-ray crystallographic analysis. These findings help understand the dehydration/hydration mechanism as well as the physicochemical properties of pharmaceutical crystals.

Supplementary Materials: The following are available online at https:/ / www.mdpi.com/article/10 .3390 / cryst11040412/s1, Figure S1: DSC diagram of DIC-Na 4.75H, Table S1: Crystal structures of diclofenac sodium (DIC-Na) hydrates published thus far.

Author Contributions: Conceptualization, H.O., T.M. and H.U. Structural analysis, H.O. and T.M. Investigation, H.O., T.M. and I.N. Writing-original draft preparation, H.O. and T.M. Writingreview and editing, H.O., A.S. and H.U. Visualization, H.O. Supervision, A.S. and H.U. Project administration, H.U. All authors have read and agreed to the published version of the manuscript.

Funding: Part of this work was supported by JSPS KAKENHI Grant Number JP18H04504 and $20 \mathrm{H} 04661$ (H.U.).

Data Availability Statement: CCDC 2065083, 2065085, and 2065086 contains the supplementary crystallographic data for this paper $(3.5 \mathrm{H}, 4.75 \mathrm{H}$, and $\mathrm{AH}$, respectively). These data can be obtained free of charge from The Cambridge Crystallographic Data Centre via www.ccdc.cam.ac.uk/structures.

Acknowledgments: The authors are thankful to Etsuo Yonemochi (Hoshi University) for the DVS measurement.

Conflicts of Interest: The authors declare no conflict of interest.

\section{References}

1. Leuner, C.; Dressman, J. Improving drug solubility for oral delivery using solid dispersions. Eur. J. Pharm. Biopharm. 2000, 50, 47-60. [CrossRef]

2. Ma, X.; Müller, F.; Huang, S.; Lowinger, M.; Liu, X.; Schooler, R.; Williams, R.O., III. Influence of Carbamazepine Dihydrate on the Preparation of Amorphous Solid Dispersions by Hot Melt Extrusion. Pharmaceutics 2020, 12, 379. [CrossRef] [PubMed]

3. Vikas, Y.; Sandeep, K.; Braham, D.; Manjusha, C.; Budhwar, V. Cyclodextrin complexes: An approach to improve the physicochemical properties of drugs and applications of cyclodextrin complexes. Asian J. Pharm. 2018, 12, S394.

4. Pang, H.; Sun, Y.-B.; Zhou, J.-W.; Xie, M.-J.; Lin, H.; Yong, Y.; Chen, L.-Z.; Fang, B.-H. Pharmaceutical Salts of Enrofloxacin with Organic Acids. Crystals 2020, 10, 646. [CrossRef]

5. Karimi-Jafari, M.; Padrela, L.; Walker, G.M.; Croker, D.M. Creating Cocrystals: A Review of Pharmaceutical Cocrystal Preparation Routes and Applications. Cryst. Growth Des. 2018, 18, 6370-6387. [CrossRef]

6. Childs, S.L.; Chyall, L.J.; Dunlap, J.T.; Smolenskaya, V.N.; Stahly, B.C.; Stahly, G.P. Crystal Engineering Approach to Forming Cocrystals of Amine Hydrochlorides with Organic Acids. Molecular Complexes of Fluoxetine Hydrochloride with Benzoic, Succinic, and Fumaric Acids. J. Am. Chem. Soc. 2004, 126, 13335-13342. [CrossRef] 
7. Takata, N.; Tanida, S.; Nakae, S.; Shiraki, K.; Tozuka, Y.; Ishigai, M. Tofogliflozin Salt Cocrystals with Sodium Acetate and Potassium Acetate. Chem. Pharm. Bull. 2018, 66, 1035-1040. [CrossRef] [PubMed]

8. Wang, L.-Y.; Bu, F.-Z.; Li, Y.-T.; Wu, Z.-Y.; Yan, C.-W. A Sulfathiazole-Amantadine Hydrochloride Cocrystal: The First Codrug Simultaneously Comprising Antiviral and Antibacterial Components. Cryst. Growth Des. 2020, 20, 3236-3246. [CrossRef]

9. Gould, P.L. Salt selection for basic drugs. Int. J. Pharm. 1986, 33, 201-217. [CrossRef]

10. Serajuddin, A.T.M. Salt formation to improve drug solubility. Adv. Drug Deliv. Rev. 2007, 59, 603-616. [CrossRef]

11. Paulekuhn, G.S.; Dressman, J.B.; Saal, C. Trends in Active Pharmaceutical Ingredient Salt Selection based on Analysis of the Orange Book Database. J. Med. Chem. 2007, 50, 6665-6672. [CrossRef] [PubMed]

12. Dzidic, I.; Kebarle, P. Hydration of the alkali ions in the gas phase. Enthalpies and entropies of reactions $\mathrm{M}^{+}\left(\mathrm{H}_{2} \mathrm{O}\right)_{\mathrm{n}-1}+\mathrm{H}_{2} \mathrm{O}=$ $\mathrm{M}^{+}\left(\mathrm{H}_{2} \mathrm{O}\right)_{n}$. J. Phys. Chem. 1970, 74, 1466-1474. [CrossRef]

13. Stephenson, G.A.; Diseroad, B.A. Structural relationship and desolvation behavior of cromolyn, cefazolin and fenoprofen sodium hydrates. Int. J. Pharm. 2000, 198, 167-177. [CrossRef]

14. Banerjee, R.; Bhatt, P.M.; Kirchner, M.T.; Desiraju, G.R. Structural studies of the system $\mathrm{Na}\left(\right.$ saccharinate) $n \mathrm{H}_{2} \mathrm{O}: \mathrm{A}$ model for crystallization. Angew. Chem. Int. Ed. 2005, 44, 2515-2520. [CrossRef]

15. Bond, A.D.; Cornett, C.; Larsen, F.H.; Qu, H.; Raijada, D.; Rantanen, J. Structural basis for the transformation pathways of the sodium naproxen anhydrate-hydrate system. IUCrJ 2014, 1, 328-337. [CrossRef]

16. Dračínský, M.; Šála, M.; Hodgkinson, P. Dynamics of water molecules and sodium ions in solid hydrates of nucleotides. CrystEngComm 2014, 16, 6756-6764. [CrossRef]

17. Spielberg, E.T.; Campbell, P.S.; Szeto, K.C.; Mallick, B.; Schaumann, J.; Mudring, A. Sodium Salicylate: An In-Depth Thermal and Photophysical Study. Chem. Eur. J. 2018, 24, 15638-15648. [CrossRef] [PubMed]

18. Shah, H.S.; Chaturvedi, K.; Zeller, M.; Bates, S.; Morris, K. A threefold superstructure of the anti-epileptic drug phenytoin sodium as a mixed methanol solvate hydrate. Acta Cryst. 2019, C75, 1213-1219. [CrossRef] [PubMed]

19. Ding, Z.; Su, W.; Huang, X.; Tian, B.; Cheng, X.; Mao, Y.; Li, G.; Liu, H.; Hao, H. Understanding the Role of Water in Different Solid Forms of Avibactam Sodium and Its Affecting Mechanism. Cryst. Growth Des. 2020, 20, 1150-1161. [CrossRef]

20. Fujii, K.; Aoki, M.; Uekusa, H. Solid-State Hydration/Dehydration of Erythromycin an Investigated by ab Initio Powder X-ray Diffraction Analysis: Stoichiometric and Nonstoichiometric Dehydrated Hydrate. Cryst. Growth Des. 2013, 13, 2060-2066. [CrossRef]

21. Mizoguchi, R.; Uekusa, H. Elucidating the Dehydration Mechanism of Ondansetron Hydrochloride Dihydrate with a Crystal Structure. Cryst. Growth Des. 2018, 18, 6142-6149. [CrossRef]

22. Griesser, U.J. The Importance of Solvates. In Polymorphism in the Pharmaceutical Industry; Wiley: Weinheim, Germany, 2006; pp. 211-233.

23. Jurczak, E.; Mazurek, A.H.; Szeleszczuk, Ł.; Pisklak, D.M.; Zielińska-Pisklak, M. Pharmaceutical Hydrates Analysis-Overview of Methods and Recent Advances. Pharmaceutics 2020, 12, 959. [CrossRef] [PubMed]

24. Rietveld, I.B.; Céolin, R. Rotigotine: Unexpected Polymorphism with Predictable Overall Monotropic Behavior. J. Pharm. Sci. 2015, 104, 4117-4122. [CrossRef] [PubMed]

25. Fujii, K.; Uekusa, H.; Itoda, N.; Hasegawa, G.; Yonemochi, E.; Terada, K.; Pan, Z.; Harris, K.D.M. Physicochemical under-standing of polymorphism and solid-state dehydration/rehydration processes for the pharmaceutical material acrinol, by ab initio powder X-ray diffraction analysis and other techniques. J. Phys. Chem. 2010, 114, 580-586.

26. Suzuki, T.; Terada, K. Elucidation of the crystal structure-physicochemical property relationship among polymorphs and hydrates of sitafloxacin, a novel fluoroquinolone antibiotic. Int. J. Pharm. 2012, 422, 1-8. [CrossRef]

27. Khomane, K.S.; More, P.K.; Raghavendra, G.; Bansal, A.K. Molecular understanding of the compaction behavior of indo-methacin polymorphs. Mol. Pharm. 2013, 10, 631-639. [CrossRef]

28. Datta, S.; Grant, D.J.W. Crystal structures of drugs: Advances in determination, prediction and engineering. Nat. Rev. Drug Discov. 2004, 3, 42-57. [CrossRef]

29. Sakon, A.; Sekine, A.; Uekusa, H. Powder Structure Analysis of Vapochromic Quinolone Antibacterial Agent Crystals. Cryst. Growth Des. 2016, 16, 4635-4645. [CrossRef]

30. Putra, O.D.; Pettersen, A.; Yonemochi, E.; Uekusa, H. Structural origin of physicochemical properties differences upon dehydration and polymorphic transformation of ciprofloxacin hydrochloride revealed by structure determination from powder X-ray diffraction data. Cryst. Eng. Comm. 2020, 22, 7272-7279. [CrossRef]

31. Skomski, D.; Varsolona, R.J.; Su, Y.; Zhang, J.; Teller, R.; Forster, S.P.; Barrett, S.E.; Xu, W. Islatravir Case Study for Enhanced Screening of Thermodynamically Stable Crystalline Anhydrate Phases in Pharmaceutical Process Development by Hot Melt Extrusion. Mol. Pharm. 2020, 17, 2874-2881. [CrossRef]

32. Takagi, T.; Ramachandran, C.; Bermejo, M.; Yamashita, S.; Yu, L.X.; Amidon, G.L. A provisional biopharmaceutical classification of the top 200 oral drug products in the United States, Great Britain, Spain and Japan. Mol. Pharm. 2006, 3, 631-643. [CrossRef]

33. Muangsin, N.; Prajaubsook, M.; Chaichit, N.; Siritaedmukul, K.; Hannongbua, S. Crystal Structure of a Unique Sodium Distorted Linkage in Diclofenac Sodium Pentahydrate. Anal. Sci. 2002, 18, 967-968. [CrossRef]

34. Llinàs, A.; Burley, J.C.; Box, K.J.; Glen, R.C.; Goodman, J.M. Diclofenac Solubility: Independent Determination of the Intrinsic Solubility of Three Crystal Forms. J. Med. Chem. 2007, 50, 979-983. [CrossRef] 
35. Reck, G.; Faust, G.; Dietz, G. X-ray crystallographic studies of diclofenac-sodium-Structural analysis of diclofenac-sodium tetrahydrate. Die Pharm. 1988, 43, 771-774.

36. Bartolomei, M.; Rodomonte, A.; Antoniella, E.; Minelli, G.; Bertocchi, P. Hydrate modifications of the non-steroidal antiinflammatory drug diclofenac sodium: Solid-state characterisation of a trihydrate form. J. Pharm. Biochem. Anal. 2007, 45, 443-449. [CrossRef]

37. Nieto, I.A.; Bernès, S.; Pérez-Benítez, A. Crystal structure of a new hydrate form of the NSAID sodium diclofenac. Acta Crystallogr. Sect. E Crystallogr. Commun. 2020, 76, 1846-1850. [CrossRef]

38. Shah, S.R.; Shah, Z.; Khan, A.; Ahmed, A.; Sohani; Hussain, J.; Csuk, R.; Anwar, M.U.; Al-Harrasi, A. Sodium, Potassium, and Lithium Complexes of Phenanthroline and Diclofenac: First Report on Anticancer Studies. ACS Omega 2019, 25, 21559-21566. [CrossRef] [PubMed]

39. Nugrahani, I.; Kumalasari, R.A.; Auli, W.N.; Horikawa, A.; Uekusa, H. Salt Cocrystal of Diclofenac Sodium-L-proline: Structural, Pseudopolymorphism, and Pharmaceutics Performance Study. Pharmaceutics 2020, 12, 690. [CrossRef]

40. Spek, A.L. Structure validation in chemical crystallography. Acta Crystallogr. Sect. D Biol. Crystallogr. 2009, D65, 148-155. [CrossRef] [PubMed]

41. Sheldrick, G.M. SHELXT-Integrated space-group and crystal-structure determination. Acta Cryst. 2015, A71, 3-8. [CrossRef] [PubMed]

42. Sheldrick, G.M. Crystal structure refinement with SHELXL. Acta Cryst. 2015, C71, 3-8. [CrossRef]

43. Macrae, C.F.; Sovago, I.; Cottrell, S.J.; Galek, P.T.A.; McCabe, P.; Pidcock, E.; Platings, M.; Shields, G.P.; Stevens, J.S.; Towler, M.; et al. Mercury 4.0: From visualization to analysis, design and prediction. J. Appl. Crystallogr. 2020, 53, 226-235. [CrossRef] [PubMed]

44. Fifen, J.J.; Agmon, N. Structure and Spectroscopy of Hydrated Sodium Ions at Different Temperatures and the Cluster Stability Rules. J. Chem. Theory Comput. 2016, 12, 1656-1673. [CrossRef] [PubMed] 